\title{
"Price and Value of Electronic Journals: A Survey at the Indian Institute of Science"
}

\author{
Golnessa GALYANI MOGHADDAM \\ Faculty of Dept. of Library and Information Science, Shahed University, Tehran, IRAN. \\ E-mail: g_galyani@yahoo.com
}

\begin{abstract}
:
This paper focuses on analyzing the most used scholarly electronic journals at a multidisciplinary research institute in India, the Indian Institute of Science (IISc). Analysis of the top thirty journals at IISc showed that two-thirds of the thirty top journals belong to non-profit/society publishers and one-third belongs to for-profit/commercial publishers. There is a remarkable difference between the prices that for-profit/commercial publishers charge to libraries for scholarly journals and the prices that non-profit/ society publishers and university presses charge. This price difference does not appear to reflect a difference in quality as measured by number of recorded citations to a journal/impact factor and use of journal.
\end{abstract}

Key Words: Scholarly Journals, Journal Price, Usage Study, Indian Institute of Science, India

\section{Introduction}

Researchers use journals for their inherent value - as perceived by them. Generally, researchers do not categorize journals based on their ownership. However, an attempt is made here to analyse the top thirty journals used at the Indian Institute of Science (IISc), located in Bangalore, India. The objective is to find any relation between use and value as measured by impact factor, price and value.

The Indian Institute of Science is an institute of higher learning and is one of the oldest and finest centres of its kind in India, and has a high international standing in the academic world as well. The Institute had electronic access to around 6000 journals from different publishers in 2004. The Institute subscribed to all the electronic journals from the following six publishers: Elsevier, Springer-Verlag, ASCE (American Society for Civil Engineering), IEEE, ACM Press, Institute of Physics in UK and USA. In addition, users had access to science and technology journals in specialized areas from more than one hundred publishers all over the world. Internet facilities are available in all departments and researchers have 24 -hour access to electronic journals.

The data has been extracted from a user study of scholarly journals which had been carried out by the author at the Indian Institute of Science in 2004. That study had sought to investigate scholarly journals usage in a multi-disciplinary institute in order to see usage pattern across different subjects (1). The respondents were asked to list the titles of journals that they use regularly to identify the most used journals and to see 
how the journals were being used. From the total 562 journals (titles) mentioned by the Institute's users, the top 30 journals were further analyzed for this study.

\title{
Literature Review
}

It seems that the first study regarding differences between commercial and non-profit publishers appeared in the literature two decades ago. In 1986, Henry Barschall looked at the costs of a small sample of physics journals (20 titles), as well as an even smaller number of philosophy and mathematics journals. Barschall employed a methodology previously used by the American Mathematical Society and others: comparison of costs per 1000 characters. He concluded that:

\begin{abstract}
While one would expect journals published by not-for-profit publishers to be less expensive than those published by commercial publishers, the cost-percharacter ratio of over 40 between the most expensive commercial [at $\$ 0.31$ per 1000] and the least expensive not-for-profit publication [at \$0.007] is larger than one might have expected. We found the variation to be similar for mathematics and physics journals (Barschall, 1986).
\end{abstract}

Two years later, Barschall conducted another study using a much larger sample of over 200 physics journals. The results of this study confirmed the results of the earlier study (Barschall, 1988).

Loughner published a study in 1999 of the library budget at the University of Georgia. He concluded from the data he had gathered that a larger and larger proportion of library budget was going to a small number of major publishers. The library spent $76 \%$ of its science journal budget for publications from the top ten publishers. This was up from $54 \%$ in 1990 . The list of the ten publishers that it spent the most money with in 1990 and 1999 included Elsevier, Springer, Wiley, Harcourt, Taylor \& Francis, Blackwell, Kluwer, Plenum, Gordon Breach and Marcel Dekker (Loughner, 1999).

In "Free Labor for Costly Journals?" Bergstrom reported on a price comparison of economics journals from non-profit and commercial publishers. The results showed that the six most-cited economics journals listed in the Social Science Citation Index were all non-profit journals and their library subscription prices averaged about $\$ 180$ per year. Only five of the twenty most-cited journals were owned by commercial publishers, and the average price of these five journals was about $\$ 1,660$ per year. The average price per page (calculated by dividing year 2001 prices by the number of pages published in the year 2000) of the commercial journals was about six times as high, and the average price per citation was about sixteen times as high as for the non-profit journals. The differences in prices and cost-effectiveness between non-profit and commercial journals were similar for less prestigious journals (Bergstrom, 2001).

Pricing studies by librarians show that the pattern found in economics is common to many disciplines. Commercial journals are more expensive than journals published by professional societies, but the most-cited and influential journals are almost universally those published at lower cost by professional societies. For example, Wilder found that about 50 percent of all citations in chemistry came from journals published by professional societies, but expenditure on these journals constituted only about 25 percent of library subscription costs for chemistry journals (Wilder, 1998). 
Another price study published by Bergstrom and Bergstrom in 2004 revealed a startling difference between the prices that university libraries must pay for academic journals from commercial publishers and the prices they pay for journals from professional societies and university presses. For example, in the fields of economics and ecology, the average institutional subscription price per page charged by commercial journals is about five times that charged by non-profit journals. These price differences do not reflect differences in quality as measured by number of recorded citations to a journal. For commercial journals the average price per citation is about fifteen times that for nonprofit journals. Similar price differentials were found across a wide variety of scientific disciplines. These price differences had increased rapidly in fifteen years. The average real (adjusted for inflation) price per page for journals from commercial publishers had increased by $300 \%$ since 1985 , while that of non-profit economics journals had increased by 50 percent (Bergstrom and Bergstrom, 2004).

A report on a study in Publishers Weekly stated:

\begin{abstract}
"While many university libraries face severe budget cuts, large commercial publishers in the academic journal market have enjoyed increasing profits. In 2002 , for instance, revenue rose $26 \%$ and operating profit increased to $25 \%$ for Elsevier, the largest journal publisher in the science, technology, and medical field." (Sales and Earning, 2003).
\end{abstract}

Pricing studies across subjects/disciplines were also reported in the literature. For example, Kean has conducted annual pricing studies for eighteen years. In the 18th Annual Study of Journal Prices for Scientific and Medical Society Journals, published in 2005, he reports that for the 251 journals studied, which were predominantly scientific and medical representing many different subject fields, the average U.S. institutional subscription price was $\$ 326.11$. The average price per issue was $\$ 43.83$ and the average journal had 7.44 issues per volume year. The pricing trends differed by discipline. For example, chemistry and physics titles, with an average 2005 price of $\$ 1,879.56$, continue to be more expensive than other subject categories surveyed (Kean, 2005).

\title{
Methodology
}

The top thirty journals at the Indian Institute of Science (IISc) were identified and ranked by the number of people reporting using them.

In the present study price per issue has been considered for analysis. The Average Subscription Price per Issue (ASPPI) has been computed based on the following formula:

$$
\text { ASPPI }=\text { Annual Subscription Price of a Journal } \div \text { Number of Issues Per Year }
$$

The annual subscription prices in US dollar have been collected from the 2004 price lists. It may be noted that US dollar has been considered for all calculations in this study and only institutional subscription prices have been considered for analysis. The exception is the "EMBO Journal" (The European Molecular Biology Organization Journal) for which the 2003 subscription price has been used for analysis. Until 2003, Oxford University Press had published the "EMBO Journal". Since January 2004, Nature Publishing Group (NPG) has been publishing the "EMBO Journal" alongside its sister journal the "EMBO Reports", which Nature Publishing Group had published since January 2003. From 2004, a subscription to the "EMBO Journal" ( 24 issues / year) will by default include 12 issues of 
"EMBO reports". This meant that a separate subscription price for the "EMBO Journal" in 2004 was not available.

The impact factor is one of the famous quantitative tools for ranking, evaluating, categorizing, and comparing journals. Since 1975, impact factors for journals have been computed by the Institute of Scientific Information (ISI), producers of the Science Citation Index and the Social Sciences Citation Index, and published in its Journal Citation Report (JCR). The impact factors do change from year to year, so the impact factor of two different years has been considered for better analysis. The impact factor of the top thirty journals used at IISc has been collected from the Journal Citation Report (JCR) for the year of 2001 and 2004.

The journals are shown in ranked order of use in Table 1, together with the name of their publishers, the 2004 annual subscription price, the number of issue per year, Average Subscription Price Per Issue (ASPPI) and the impact factor for 2004.

As is seen in Table1, the most used journal at the Indian Institute of Science was "Nature" which also had a high impact factor (32.182) in 2004. The next most used journal was "Science" with an impact factor of 31.853. The third one was PNAS (Proceedings of the National Academy of Sciences of the United States of America) with an impact factor of 10.5 in 2004. 
Table 1: The Top - Thirty Titles Used at IISc

\begin{tabular}{|c|c|c|c|c|c|c|c|}
\hline & $\begin{array}{c}\text { Title of } \\
\text { Journal } \\
\text { Ranked by } \\
\text { Number of } \\
\text { Use }\end{array}$ & $\begin{array}{l}\text { No } \\
\text { of } \\
\text { Us } \\
\text { e }\end{array}$ & $\begin{array}{l}\text { Name } \\
\text { Publisher }\end{array}$ & $\begin{array}{c}\text { Numbe } \\
\text { r of } \\
\text { Issues } \\
\text { Per } \\
\text { Year } \\
(2004)\end{array}$ & $\begin{array}{l}\text { Annual } \\
\text { Sub. } \\
\text { Price } \\
\text { US\$ } \\
(2004)\end{array}$ & $\begin{array}{l}\text { Ave. } \\
\text { Sub. Per } \\
\text { Issue } \\
\text { US\$ } \\
(2004)\end{array}$ & $\begin{array}{l}2004 \\
\text { Impact } \\
\text { Factor }\end{array}$ \\
\hline 1 & Nature & 71 & $\begin{array}{l}\text { Nature } \quad \text { Publishing } \\
\text { Group }\end{array}$ & 51 & 1,200 & 23. 53 & 32.182 \\
\hline 2 & Science & 53 & $\begin{array}{l}\text { American Association } \\
\text { for the Advancement of } \\
\text { Science }\end{array}$ & 51 & 585 & 11.47 & 31.853 \\
\hline 3 & PNAS & 31 & $\begin{array}{ll}\text { National } & \text { Academy } \\
\text { Sciences } & \end{array}$ & 26 & 2,950 & 113.46 & 10.5 \\
\hline 4 & $\begin{array}{l}\text { JACS (J of } \\
\text { Am. Ch. Soc. })\end{array}$ & 28 & $\begin{array}{l}\text { American } \\
\text { Society (ACS) }\end{array}$ & 51 & 3,244 & 63.60 & 6.903 \\
\hline 5 & $\begin{array}{l}\text { Physical } \\
\text { Review Letter }\end{array}$ & 26 & $\begin{array}{ll}\text { American } & \text { Physical } \\
\text { Society (APS) }\end{array}$ & 52 & 3,260 & 62.69 & 7.22 \\
\hline 6 & $\begin{array}{l}\text { JBC (J of } \\
\text { Biological } \\
\text { Chemistry) }\end{array}$ & 22 & $\begin{array}{lr}\text { American Society } & \text { For } \\
\text { Biochemistry } & \text { and } \\
\text { Molecular } & \text { Biology } \\
\text { (ASBMB) } & \end{array}$ & 52 & 1,950 & 37.5 & 6.482 \\
\hline 7 & $\begin{array}{l}\text { Physical } \\
\text { Review B }\end{array}$ & 15 & $\begin{array}{ll}\text { American } & \text { Physical } \\
\text { Society (APS) }\end{array}$ & 48 & 6,625 & 138.02 & 3.08 \\
\hline 8 & $\begin{array}{l}\text { Applied } \\
\text { Physics Letter }\end{array}$ & 14 & $\begin{array}{l}\text { American Institute of } \\
\text { Physics (AIP) }\end{array}$ & 52 & 2,255 & 43.36 & 4.31 \\
\hline 9 & $\begin{array}{l}\text { Biosystems } \\
\text { Engineer and } \\
\text { Biochemistry }\end{array}$ & 14 & $\begin{array}{l}\text { European Society for } \\
\text { Agriculture Engineering } \\
\text { (Elsevier) }\end{array}$ & 12 & 864 & 72 & 0.496 \\
\hline 10 & $\begin{array}{l}\text { JAP (J of } \\
\text { Applied } \\
\text { Physics) }\end{array}$ & 14 & $\begin{array}{l}\text { American Institute of } \\
\text { Physics (AIP) }\end{array}$ & $\begin{array}{ll}\text { A } & 12 \\
\text { B } & 12\end{array}$ & $\{3,360$ & $\{140$ & $\begin{array}{l}\text { A } 1.452 \\
\text { B } 2.215\end{array}$ \\
\hline 11 & $\begin{array}{l}\text { JMB (J of } \\
\text { Molecular } \\
\text { Biology) }\end{array}$ & 12 & $\begin{array}{ll}\text { Elsevier } & \text { (Academic } \\
\text { Press) } & \end{array}$ & 50 & 5,620 & 112. 40 & 5.542 \\
\hline 12 & $\begin{array}{l}\text { J of Fluid } \\
\text { Mechanics }\end{array}$ & 11 & $\begin{array}{l}\text { Cambridge University } \\
\text { Press }\end{array}$ & 24 & 1,695 & 70.63 & 1.853 \\
\hline 13 & $\begin{array}{l}\text { Angewandte } \\
\text { Chemical } \\
\text { International } \\
\text { Edition }\end{array}$ & 11 & John Wiley \& Sons, Ltd. & 24 & 4,090 & 170.42 & 9.161 \\
\hline 14 & $\begin{array}{l}\text { JCP (J of } \\
\text { Chemical } \\
\text { Physics) }\end{array}$ & 10 & $\begin{array}{l}\text { American Institute of } \\
\text { Physics (AIP) }\end{array}$ & 48 & 4,785 & 99.69 & 3.11 \\
\hline
\end{tabular}




\begin{tabular}{|c|c|c|c|c|c|c|c|}
\hline & $\begin{array}{c}\text { Title of } \\
\text { Journal } \\
\text { Ranked by } \\
\text { Number of } \\
\text { Use }\end{array}$ & $\begin{array}{l}\text { No } \\
\text { of } \\
\text { Us } \\
\text { e }\end{array}$ & $\begin{array}{l}\text { Name } \\
\text { Publisher }\end{array}$ & $\begin{array}{l}\text { Numbe } \\
\text { r of } \\
\text { Issues } \\
\text { Per } \\
\text { Year } \\
(2004)\end{array}$ & $\begin{array}{c}\text { Annual } \\
\text { Sub. } \\
\text { Price } \\
\text { US\$ } \\
(2004)\end{array}$ & $\begin{array}{l}\text { Ave. } \\
\text { Sub. Per } \\
\text { Issue } \\
\text { US\$ } \\
(2004)\end{array}$ & $\begin{array}{l}2004 \\
\text { Impact } \\
\text { Factor }\end{array}$ \\
\hline 15 & $\begin{array}{l}\text { Int. J for } \\
\text { Num. Meth. in } \\
\text { Engg. }\end{array}$ & 09 & Wiley InterScience & 36 & 7,440 & 206.66 & 1.501 \\
\hline 16 & AIAA Journal & 09 & $\begin{array}{l}\text { American Institution of } \\
\text { Aeronautics and } \\
\text { Astronautics (AIAA) }\end{array}$ & 12 & 1,120 & 93.33 & 0.870 \\
\hline 17 & ALCHE & 08 & $\begin{array}{l}\text { American Institute Of } \\
\text { Chemical Engineering }\end{array}$ & 12 & 1,140 & 95 & 1.761 \\
\hline 18 & Cell & 08 & Cell Press & 26 & 1,068 & 41.07 & 28.389 \\
\hline 19 & $\begin{array}{ll}\text { IEEE } & \text { Trans. } \\
\text { on } & \text { Signal } \\
\text { Processing }\end{array}$ & 08 & IEEE & 12 & 1,075 & 82.69 & 1.76 \\
\hline 20 & $\begin{array}{l}\text { The EMBO J } \\
\text { (Eu. Mo. Bio.) }\end{array}$ & 07 & Nature Publishing Group & 24 & 1,425 & 59.37 & 10.456 \\
\hline 21 & $\begin{array}{l}\text { JOC (J of } \\
\text { Organic } \\
\text { Chemistry) }\end{array}$ & 07 & $\begin{array}{l}\text { American Chemical } \\
\text { Society (ACS) }\end{array}$ & 26 & 2,204 & 84. 77 & 3.462 \\
\hline 22 & $\begin{array}{l}\text { Int. J of Solids } \\
\& \text { Structures }\end{array}$ & 07 & Elsevier & 52 & 6,703 & 128. 90 & 1.378 \\
\hline 23 & $\begin{array}{l}\text { J of Physical } \\
\text { Chem. A\& B }\end{array}$ & 07 & $\begin{array}{l}\text { American } \\
\text { Society (ACS) }\end{array}$ & $\begin{array}{ll}\text { A } & 51 \\
\text { B } & 51\end{array}$ & $\begin{array}{c}\{ \\
4262\end{array}$ & $\begin{array}{c}\{41 \\
78\end{array}$ & $\begin{array}{c}\text { A } \\
2.639 \\
\text { B } 3.834\end{array}$ \\
\hline 24 & $\begin{array}{l}\text { Physical } \\
\text { Review-E }\end{array}$ & 07 & $\begin{array}{ll}\text { American } & \text { Physical } \\
\text { Society (APS) } & \end{array}$ & 12 & 2,580 & 215 & 2.35 \\
\hline 25 & $\begin{array}{l}\text { Acta } \\
\text { Materialia }\end{array}$ & 06 & Elsevier & 18 & 2,758 & 153.22 & 3.490 \\
\hline 26 & $\begin{array}{l}\text { J of Sound } \\
\text { and Vibration }\end{array}$ & 06 & Elsevier & 50 & 6,058 & 121.16 & 0.828 \\
\hline 27 & $\begin{array}{l}\text { Biotechnology } \\
\text { \& Bioengg. }\end{array}$ & 06 & Wiley InterScience & 25 & 4,995 & 199. 80 & 3.316 \\
\hline 28 & $\begin{array}{l}\text { Physics of } \\
\text { Fluids }\end{array}$ & 06 & $\begin{array}{l}\text { American Institute of } \\
\text { Physics (AIP) }\end{array}$ & 12 & 1,965 & 163.75 & 1.76 \\
\hline 29 & $\begin{array}{l}\text { Physical } \\
\text { Review- A }\end{array}$ & 06 & $\begin{array}{ll}\text { American } & \text { Physical } \\
\text { Society (APS) } & \end{array}$ & 12 & 2,410 & 200.83 & 2.90 \\
\hline 30 & $\begin{array}{l}\text { Physical } \\
\text { Review-C }\end{array}$ & 06 & $\begin{array}{ll}\text { American } & \text { Physical } \\
\text { Society (APS) } & \end{array}$ & 12 & 1,885 & 157.08 & 3.13 \\
\hline \multicolumn{4}{|c|}{ Total } & 1,008 & 91,571 & 90.84 & -- \\
\hline
\end{tabular}

Table 1: The Top - Thirty Titles Used at IISc (Continued...) 


\section{Comparison between most used journals at the Indian Institute of Science (IISc) in India and the Max Planck Society (MPG) in Germany}

The findings of this research in India are similar to an earlier study in Germany, a survey carried out at the Max Planck Society (MPG) in 1999 (Rusch-Feja and Siebeky, 1999). Both studies have carried out in a basic research organization which is similar to an academy of sciences. Both studies were cross-disciplinary and cross-organizational so the results of both studies could be seen as having exemplary character as they were not restricted to certain subject/discipline. Moreover, both studies were focused on scholarly electronic journal usage among different publishers. For these reasons, a comparison between top journals in these two studies has been made here. In order to a view at a comparison of the two studies, the most used journals at the Max Planck Society and the Indian Institute of Science have been presented in Table 2.

Comparison between "Top-Twenty Titles used at the MPG" and "Top-Twenty Titles used at the IISc" shows that four of the first six journals are common between the two studies. Interestingly, "Nature" is the most used journal in both studies, whilst "Science" is also in the top five in both lists. "Nature" is a weekly international journal and one of the world's top scientific journals. "Nature" publishes the peer-reviewed research in all fields of science and technology on the basis of its originality, importance, interdisciplinary interest, timeliness, accessibility, elegance and surprising conclusions. "Science" is also one the world's leading journal of original scientific research, global news, and commentary. It seems that journals which focus on science in general like "Nature" and "Science" are being used by the IISc researchers regardless of their discipline.

Table 2 shows that the following seven journals are common among top-twenty journals in both studies: Nature, Science, PNAS (Proceedings of the National Academy Sciences of the United States of America), JACS (Journal of the American Chemical Society), JBC (Journal of Biological Chemistry), Cell and the EMBO Journal (The European Molecular Biology Organization Journal). It is interesting to have seven common titles among toptwenty journals in these two studies. An examination of the 2004 impact factors of these seven journals shows that they also have a high impact factor according to the ISI Journal Citation Report (See Table 1).

There are some differences about other journals in two studies. This may be because in that study received more responses from "Biomedical Section" at the Max Planck Society while the present study received more responses from Departments of Physics and Chemistry at the Indian Institute of Science. 


\begin{tabular}{|c|c|c|c|c|c|}
\hline \multicolumn{3}{|c|}{ Top-twenty titles used at the MPG } & \multicolumn{3}{|c|}{ Top-twenty titles used at the IISc } \\
\hline Rank & Titles of Journals & $\begin{array}{l}\text { No. } \\
\text { of } \\
\text { Users }\end{array}$ & Rank & Titles of Journals & $\begin{array}{l}\text { No. of } \\
\text { Users }\end{array}$ \\
\hline 1 & Nature & 99 & 1 & Nature & 71 \\
\hline 2 & Cell & 59 & 2 & Science & 53 \\
\hline 3 & $\begin{array}{l}\text { JBC (Journal of Biological } \\
\text { Chemistry) }\end{array}$ & 42 & 3 & $\begin{array}{l}\text { PNAS (Proceedings of } \\
\text { the National Academy } \\
\text { Sci.) }\end{array}$ & 31 \\
\hline 4 & $\begin{array}{l}\text { PNAS (Proceedings of } \\
\text { the National Academy } \\
\text { Sciences) }\end{array}$ & 37 & 4 & $\begin{array}{l}\text { JACS (Journal of } \\
\text { American } \\
\text { Society) }\end{array}$ & 28 \\
\hline 5 & Science & 28 & 5 & Physical Review Letter & 26 \\
\hline 6 & $\begin{array}{lr}\text { EMBO } & \text { Journal (The } \\
\text { European } & \text { Molecular } \\
\text { Biology } & \text { Organization J.) }\end{array}$ & 25 & 6 & $\begin{array}{l}\text { JBC (Journal of } \\
\text { Biological Chemistry) }\end{array}$ & 22 \\
\hline 7 & Neuron & 25 & 7 & Physical Review B & 15 \\
\hline 8 & Development & 19 & 8 & Applied Physics Letter & 14 \\
\hline 9 & Nature Neuroscience & 16 & 9 & $\begin{array}{l}\text { Biosystems Engineer } \\
\text { and Biochemistry }\end{array}$ & 14 \\
\hline 10 & Genes and Development & 14 & 10 & $\begin{array}{l}\text { JAP (Journal of Applied } \\
\text { Physics) }\end{array}$ & 14 \\
\hline 11 & Biochemistry & 13 & 11 & $\begin{array}{l}\text { JMB (Journal of } \\
\text { Molecular Biology) }\end{array}$ & 12 \\
\hline 12 & Journals of Neuroscience & 12 & 12 & $\begin{array}{l}\text { Journal of } \quad \text { Fluid } \\
\text { Mechanics }\end{array}$ & 11 \\
\hline 13 & Biophysical Journal & 10 & 13 & $\begin{array}{l}\text { Angewandte Chemical } \\
\text { International Edition }\end{array}$ & 11 \\
\hline 14 & $\begin{array}{lll}\text { NAR (Nucleic } & \text { Acid } \\
\text { Research) } & \\
\end{array}$ & 10 & 14 & $\begin{array}{ll}\text { JCP } \quad \text { (Journal } & \text { of } \\
\text { Chemical Physics) } & \\
\end{array}$ & 10 \\
\hline 15 & Current Biology & 10 & 15 & $\begin{array}{l}\text { International Journal for } \\
\text { Numerical Methods in } \\
\text { Eng }\end{array}$ & 09 \\
\hline 16 & Nature Medicine & 09 & 16 & $\begin{array}{lr}\text { AIAA Journal (American } \\
\text { Institution } & \text { of } \\
\text { Aeronautics } & \text { and } \\
\text { Astronautics) } & \\
\end{array}$ & 09 \\
\hline 17 & Molecular Cell & 09 & 17 & $\mathrm{ALCHE}$ & 08 \\
\hline 18 & Nature Genetics & 09 & 18 & Cell & 08 \\
\hline 19 & Journal of Cell Biology & 09 & 19 & $\begin{array}{lll}\text { IEEE Transaction on } \\
\text { Signal Processing }\end{array}$ & 08 \\
\hline 20 & $\begin{array}{l}\text { JACS (Journal of the } \\
\text { American } \\
\text { Society) }\end{array}$ & 08 & 20 & $\begin{array}{l}\text { EMBO Journal (The } \\
\text { European Molecular } \\
\text { Biology Organization J.) }\end{array}$ & 07 \\
\hline
\end{tabular}

Table 2: Top-twenty Titles Used at the MPG and the IISc 


\section{Price and value of electronic journals: comparison and correlation}

Table 1 reveals that three top journals at the Indian Institute of Science including "Nature", "Science", and "Cell" have an impact factor above 20 at the ISI Journal Citation Report. This confirms that the journals with high impact factor are attracting researchers in India as much as all over the world.

Table 1 indicates that the most expensive journal among the top-thirty used at IISc was "The International Journal for Numerical Methods in Engineering" which is published by a for-profit publisher, namely Wiley InterScience. The price per issue in 2004 for this journal was US $\$ 206.6$ and the impact factor was 1.501 . The least expensive journal was "Science" which is published by a not-for-profit publisher, namely the American Association for the Advancement of Science. The price per issue for this journal was only US\$11.47 while its impact factor was 31.853. In order to obtain a more realistic comparison of price, the top-thirty journals have been categorized by types of publisher in Table 3 and Table 4. The total subscription price for each group has been calculated.

The journals in Table 3 and 4 are also ranked by their impact factors in 2001 and 2004 . Comparison between impact factors in 2001 and 2004 shows that the impact factors of twenty of the thirty-top journals have increased since 2001. However, while the impact factor of these journals has differed between these years, the impact factors of the topthirty journals have not substantially increased since 2001, except in the case of "Science" and "Nature". The impact factor of "Science" increased from 23.329 in 2001 to 31.853 in 2004 and the impact factor of "Nature" rose from 27.955 in 2001 to 32.182 in 2004.

The impact factor of scholarly journals appears to be an important parameter for researchers at the Indian Institute of Science (IISc) in determining which journals to use. It is seen from Table 3 and 4 that the top-thirty journal at this institute have high impact factors in the ISI Journal Citation Report. Journals' impact factor is becoming an increasingly important parameter for evaluating journals all around the world. Moreover, publishers of journals consider the impact factors to describe the importance of their journals among the research community. In most cases, the latest impact factors of journals are mentioned in the publishers' websites to show their prestige and importance. However, there are some debates regarding the suitability of impact factor for considering quality of journals, but for example Hoeffel commented that:

"Impact Factor is not a perfect tool to measure the quality of articles but there is nothing better and it has the advantage of already being in existence and is, therefore, a good technique for scientific evaluation. Experience has shown that in each specialty the best journals are those in which it is most difficult to have an article accepted, and these are the journals that have a high impact factor. These journals existed long before the impact factor was devised. The use of impact factor as a measure of quality is widespread because it fits well with the opinion we have in each field of the best journals in our specialty." (Hoeffel, 1998)

Table 3 and Table 4 show that two-third of thirty top journals belongs to nonprofit/society publishers and only one-third of top journals belong to forprofit/commercial publishers. The ratio of top- thirty journals ownership among society and commercial publishers is 63:36. 
These tables show that nineteen journals from top-thirty journals at the Indian Institute of Science published by non-profit/society publishers while only eleven journals published by for-profit/commercial publishers. Among these 11 journals, 5 journals are published by Elsevier, 2 journals by Wiley InterScience, 2 journals by Nature Publishing Group and only one journal is published by Cell Press.

Table 3 shows that the following three non-profit/society publishers published 12 of the top journals at IISc: American Physical Society - 5 journals, American Institute of Physics - 4 journals, and American Chemical Society- 3 journals.

\begin{tabular}{|c|c|c|c|c|c|c|c|}
\hline sn & $\begin{array}{l}\text { Title of } \\
\text { Journals } \\
\text { Ranked by } \\
2004 \text { Impact } \\
\text { Factor }\end{array}$ & $\begin{array}{l}\text { No } \\
\text { of } \\
\text { Us } \\
\text { ers }\end{array}$ & $\begin{array}{l}\text { Name of } \\
\text { Publishers }\end{array}$ & $\begin{array}{l}2004 \\
\text { Sub. } \\
\text { Price } \\
\text { US\$ }\end{array}$ & $\begin{array}{l}\text { Price } \\
\text { per } \\
\text { Issue } \\
\text { US\$ }\end{array}$ & $\begin{array}{l}2001 \\
\text { Impact } \\
\text { Factor }\end{array}$ & $\begin{array}{l}2004 \\
\text { Impact } \\
\text { Factor }\end{array}$ \\
\hline 1 & Nature & 71 & $\begin{array}{l}\text { Nature Publishing } \\
\text { Group }\end{array}$ & 1,200 & 23.53 & 27.955 & 32.182 \\
\hline 2 & Cell & 08 & Cell Press & 1,068 & 41.07 & 29.219 & 28.389 \\
\hline 3 & $\begin{array}{l}\text { The EMBO J } \\
\text { (Eu. Mol. Bio) }\end{array}$ & 07 & $\begin{array}{l}\text { Nature Publishing } \\
\text { Group }\end{array}$ & 1,425 & 59.37 & 12.459 & 10.456 \\
\hline 4 & $\begin{array}{l}\text { Angewandte } \\
\text { Chem. Int. Ed }\end{array}$ & 11 & $\begin{array}{l}\text { John Wiley \& Sons, } \\
\text { Ltd. }\end{array}$ & 4,090 & 170.42 & 8.255 & 9.161 \\
\hline 5 & $\begin{array}{l}\text { JMB (J of } \\
\text { Mole. Biolo.) }\end{array}$ & 12 & $\begin{array}{l}\text { Elsevier (Academic } \\
\text { Press) }\end{array}$ & 5,620 & 112.40 & 5.826 & 5.542 \\
\hline 6 & $\begin{array}{l}\text { Acta } \\
\text { Materialia }\end{array}$ & 06 & Elsevier & 2,758 & 153.22 & 2.658 & 3.490 \\
\hline 7 & $\begin{array}{l}\text { Biotechnology } \\
\text { \& Bioengg. }\end{array}$ & 06 & Wiley InterScience & 4,995 & 199.80 & 2.037 & 3.316 \\
\hline 8 & $\begin{array}{l}\text { Int. J for } \\
\text { Num. Meth. in } \\
\text { Engg. }\end{array}$ & 09 & Wiley InterScience & 7,440 & 206.66 & 1.239 & 1.501 \\
\hline 9 & $\begin{array}{l}\text { Int. J of Solids } \\
\& \text { Structures }\end{array}$ & 07 & Elsevier & 6,703 & 128.90 & 1.073 & 1.378 \\
\hline 10 & $\begin{array}{l}\text { J of Sound } \\
\text { and Vibration }\end{array}$ & 06 & Elsevier & 6,058 & 121.16 & 0.821 & 0.828 \\
\hline 11 & $\begin{array}{l}\text { Biosystems } \\
\text { Engineering }\end{array}$ & 14 & $\begin{array}{l}\text { Elsevier (European } \\
\text { Society for Agr. } \\
\text { Eng.) }\end{array}$ & 864 & 72 & 0.736 & 0.496 \\
\hline \multicolumn{4}{|c|}{ Total } & 42,221 & 114.73 & - & - \\
\hline
\end{tabular}

Table 3: For-profit/Commercial-Publisher-Owned Top Journals at the IISc 


\begin{tabular}{|c|c|c|c|c|c|c|c|}
\hline SN & $\begin{array}{l}\text { Title of } \\
\text { Journals } \\
\text { Ranked by } \\
2004 \text { IF } \\
\end{array}$ & $\begin{array}{l}\text { No } \\
\text { of } \\
\text { Use }\end{array}$ & $\begin{array}{l}\text { Name of } \\
\text { Publishers }\end{array}$ & $\begin{array}{l}2004 \\
\text { Sub. } \\
\text { Price } \\
\text { US\$ }\end{array}$ & $\begin{array}{l}\text { Price } \\
\text { per } \\
\text { Issue } \\
\text { US\$ } \\
\end{array}$ & $\begin{array}{l}2001 \\
\text { Impact } \\
\text { Factor }\end{array}$ & $\begin{array}{l}2004 \\
\text { Impact } \\
\text { Factor }\end{array}$ \\
\hline 1 & Science & 53 & $\begin{array}{l}\text { American } \\
\text { Association for the } \\
\text { Advancement of } \\
\text { Science }\end{array}$ & 585 & 11.47 & 23.329 & 31.853 \\
\hline 2 & $\begin{array}{l}\text { PNAS } \\
\text { (Proceedings } \\
\text { of National } \\
\text { Academy Sc) } \\
\end{array}$ & 31 & $\begin{array}{l}\text { National Academy } \\
\text { Sciences }\end{array}$ & 2,950 & 113.46 & 10.896 & 10.50 \\
\hline 3 & $\begin{array}{l}\text { Physical } \\
\text { Review } \\
\text { Letter }\end{array}$ & 26 & $\begin{array}{l}\text { American Physical } \\
\text { Society (APS) }\end{array}$ & 3,260 & 62.69 & 6.668 & 7.22 \\
\hline 4 & $\begin{array}{l}\text { JACS (J of } \\
\text { Am. } \\
\text { Chemical } \\
\text { Society) }\end{array}$ & 28 & $\begin{array}{l}\text { American } \\
\text { Chemical Society } \\
\text { (ACS) }\end{array}$ & 3,244 & 63.60 & 6.079 & 6.903 \\
\hline 5 & $\begin{array}{l}\text { JBC (J of } \\
\text { Biological } \\
\text { Chemistry) }\end{array}$ & 22 & $\begin{array}{ll}\text { Am. Soci. } & \text { For } \\
\text { Biochem. \& } & \text { Mol. } \\
\text { Biology (ASBMB) }\end{array}$ & 1,950 & 37.5 & 7.258 & 6.482 \\
\hline 6 & $\begin{array}{l}\text { Applied } \\
\text { Phy. Letter }\end{array}$ & 14 & $\begin{array}{l}\text { American Institute } \\
\text { of Physics (AIP) }\end{array}$ & 2,255 & 43.36 & 3.849 & 4.310 \\
\hline 7 & $\begin{array}{l}\text { J of Physical } \\
\text { Chem A\& B }\end{array}$ & 07 & $\begin{array}{l}\text { American Chem. } \\
\text { Society (ACS) }\end{array}$ & $\{4,262$ & $\{41.78$ & $\begin{array}{l}\text { A } 2.630 \\
\text { B } 3.379 \\
\end{array}$ & $\begin{array}{l}\text { A } 2.639 \\
\text { B } 3.834 \\
\end{array}$ \\
\hline 8 & $\begin{array}{l}\text { JOC (J of } \\
\text { Organic } \\
\text { Chemistry) }\end{array}$ & 07 & $\begin{array}{l}\text { American } \\
\text { Chemical Society } \\
\text { (ACS) }\end{array}$ & 2,204 & 84.77 & 3.280 & 3.462 \\
\hline 9 & $\begin{array}{l}\text { Physical } \\
\text { Review-C }\end{array}$ & 06 & $\begin{array}{l}\text { American Physical } \\
\text { Society (APS) }\end{array}$ & 1,885 & 157.08 & 2.695 & 3.13 \\
\hline 10 & $\begin{array}{l}\text { JCP (J of } \\
\text { Chem. Phy) }\end{array}$ & 10 & $\begin{array}{l}\text { American Institute } \\
\text { of Physics (AIP) }\end{array}$ & 4,785 & 99.69 & 3.147 & 3.11 \\
\hline 11 & $\begin{array}{l}\text { Physical } \\
\text { Review B }\end{array}$ & 15 & $\begin{array}{l}\text { American Physical } \\
\text { Society (APS) }\end{array}$ & 6,625 & 138.02 & 3.070 & 3.08 \\
\hline 12 & $\begin{array}{l}\text { Physical } \\
\text { Review- A }\end{array}$ & 06 & $\begin{array}{l}\text { American Physical } \\
\text { Society (APS) }\end{array}$ & 2,410 & 200.83 & 2.810 & 2.90 \\
\hline 13 & $\begin{array}{l}\text { Physical } \\
\text { Review-E }\end{array}$ & 07 & $\begin{array}{l}\text { American Physical } \\
\text { Society (APS) }\end{array}$ & 2,580 & 215 & 2.235 & 2.35 \\
\hline 14 & $\begin{array}{l}\text { JAP (J of } \\
\text { App. Phy.) }\end{array}$ & 14 & $\begin{array}{l}\text { American Institute } \\
\text { of Physics (AIP) }\end{array}$ & $\{3,360$ & $\{140$ & $\begin{array}{l}\text { A } 1.722 \\
\text { B } 1.984 \\
\end{array}$ & $\begin{array}{ll}\text { A } & 1.452 \\
\text { B } & 2.215 \\
\end{array}$ \\
\hline 15 & $\begin{array}{l}\text { Journal of } \\
\text { Fluid Mech. }\end{array}$ & 11 & $\begin{array}{l}\text { Cambridge } \\
\text { University Press }\end{array}$ & 1,695 & 70.63 & 1.912 & 1.853 \\
\hline 16 & ALCHE & 08 & $\begin{array}{l}\text { American Institute } \\
\text { of Chemical Eng. }\end{array}$ & 1,140 & 95 & 1.793 & 1.761 \\
\hline 17 & $\begin{array}{l}\text { IEEE Trans. } \\
\text { on Signal Pr }\end{array}$ & 08 & IEEE & 1,075 & 82.69 & 1.239 & 1.760 \\
\hline 18 & $\begin{array}{l}\text { Physics of } \\
\text { Fluids }\end{array}$ & 06 & $\begin{array}{l}\text { American Institute } \\
\text { of Physics (AIP) }\end{array}$ & 1,965 & 163.75 & 1.799 & 1.760 \\
\hline 19 & $\begin{array}{l}\text { AIAA } \\
\text { Journal }\end{array}$ & 09 & $\begin{array}{ll}\text { Am. Institution of } \\
\text { Aeronautics } & \& \\
\text { Astronautics } & \end{array}$ & 1,120 & 93.33 & 0.773 & 0.870 \\
\hline \multicolumn{4}{|c|}{ Total } & 49,350 & 77.10 & - & - \\
\hline
\end{tabular}

Table 4: Non-profit/Society-Publisher-Owned Top Journals at the IISc 
It is seen from Table 3 and Table 4 that the Indian Institute of Science has spent $\$ 42,221$ for subscription of 11 top commercial-publisher-owned journals among topthirty in 2004 and in the same time spent $\$ 49,350$ for other 19 society-publisher-owned journals.

It can be also observed from Table 3 and Table 4 that price per issue of forprofit/commercial-publisher-owned journals (11 journals) is $\$ 114.73$ and the price per issue of non-profit/society-publisher-owned (19 journals) is $\$ 77.10$. This means commercial-publisher-owned journals are about 1.4 times more expensive than nonprofit/society-publisher-owned journals.

This result is close to the findings of a broad study by author. She had made a comparison between the top four commercial publishers (Elsevier, Taylor \& Francis, Kluwer, and Blackwell) and the top four non-profit/university publishers (Oxford University Press, Cambridge University Press, IEEE, and the American Psychological Association) by average subscription price in 2003. The results had shown that the average price of the commercial publishers was 2.8 times higher than that of the nonprofit/university publishers. In addition, the price per issue of the commercial publishers was 1.8 times higher than that of the non-profit/university publishers (Galyani Moghaddam, 2006). The findings of the present study verify that in 2004 this was still the case.

Further analysis has been carried out on top-thirty journals at the Indian Institute of Science and the journals categorized based on three broad categories: Science-General, Physical and Chemical Sciences, and Biological Sciences. Table 5 shows this subject wise price analysis. In addition, the Average Subscription Price (ASP) and the Average Subscription Price per Issue (ASPPI) have been calculated and shown in Table 5.

\begin{tabular}{|c|c|c|c|c|c|c|c|c|}
\hline \multirow[t]{2}{*}{-} & \multicolumn{4}{|c|}{ For-profit Publishers of Top-Thirty } & \multicolumn{4}{|c|}{ Non-profit Publishers of Top-Thirty } \\
\hline & $\begin{array}{l}\text { No. } \\
\text { of }]\end{array}$ & $\begin{array}{l}\text { Budget } \\
\text { in 2004 } \\
\text { (\$ US) }\end{array}$ & $\begin{array}{l}\text { Average } \\
\text { Price } \\
\text { (\$US) }\end{array}$ & $\begin{array}{l}\text { Price } \\
\text { per } \\
\text { Issue } \\
\text { (\$US) }\end{array}$ & $\begin{array}{l}\text { No. } \\
\text { of J }\end{array}$ & $\begin{array}{l}\text { Budget } \\
\text { in 2004 } \\
\text { (\$ US) }\end{array}$ & $\begin{array}{l}\text { Average } \\
\text { Price } \\
\text { (\$US) }\end{array}$ & $\begin{array}{l}\text { Price } \quad p \\
(\$ \cup S)\end{array}$ \\
\hline $\begin{array}{l}\text { Science- } \\
\text { General }\end{array}$ & 1 & 1,200 & 1,200 & 23.53 & 2 & 3,535 & 1,768 & 46 \\
\hline $\begin{array}{l}\text { Physical \& } \\
\text { Chemical }\end{array}$ & 5 & 27,049 & 5,410 & 150.27 & 16 & 43,865 & 2,742 & 85.84 \\
\hline $\begin{array}{l}\text { Biological } \\
\text { Science }\end{array}$ & 5 & 13,972 & 2,795 & 102 & 1 & 1,950 & 1,950 & 37.5 \\
\hline Total & 11 & 42,221 & 3,838 & 114.73 & 19 & 49,350 & 2,597 & 77.10 \\
\hline
\end{tabular}

Table 5: Subject Wise Price of Top-Thirty Used Journals at the IISc

It is seen from Table 5 that Physical and Chemical Sciences seems to be the most costly disciplines (in term of scholarly journals) at the Indian Institute of Science among topthirty journals both for for-profit publishers and non-for-profit publishers as well. 
However, the price analysis for the top-thirty journals used at the Indian Institute of Science is based on a small number of journals in some disciplines and it is difficult to draw generalisations.

\section{Conclusion}

This study of the top thirty journals used at the Indian Institute of Science showed that the journals with a high impact factor in the Journal Citation Report are attractive for researchers in India as well as all over the world.

Impact factors have long been considered as qualitative tools to measure scholarly journals' value. However, comparison between publishers of the top journals showed that there is a considerable difference between the prices that for-profit/commercial publishers charge to libraries for scholarly journals and the prices that professional societies and university presses charge. This price difference does not reflect higher impact factors or a difference in use or perceived value.

The study showed that the Indian Institute of Science spent $\$ 49,350$ (\%54) for 19 society-publisher-owned journals and in the same time has spent $\$ 42,221$ (\%46) for subscriptions to only 11 commercial-publisher-owned journals in 2004 . Although the commercially published journals are more expensive, researchers at the Indian Institute of Science appear to use scholarly journals that are being published by non-profit/society publishers more regularly. According the result of the present study, two-thirds of thirty most used journals at the Indian Institute of Science (IISc) belong to society publishers and one-third belongs to commercial publishers. This suggests that it might be useful to spend more on subscriptions to scholarly journals from professional societies. Comparison with the study undertaken in Germany suggests that the results from IISc may not be an isolated example, and there may be general lessons that can be drawn from these studies

The librarians at the Indian Institute of Science were very interested to learn about the results of the present study. They agreed that the results of the study would help them to make better decisions regarding the Institute's scholarly journal subscriptions.

Note:

(1) The result of that study is being refereed for publication elsewhere. 


\section{References}

Barschall, Henry H. 1986. The Cost of Physics Journals. Physics Today. vol. 39, no. 12 (December): 34-36.

Barschall, Henry H. 1988. The Cost-Effectiveness of Physics Journals. Physics Today, vol. 41 , no. 7 (July): 56-59.

Bergstrom, Theodore C. 2001. Free Labor for Costly Journals? URL: http://www.econ.ucsb.edu/ tedb/Journals/jeppdf.pdf [Viewed July 15, 2002]

Bergstrom, C T. and Bergstrom, T C. 2004. The Costs and Benefits of Library Site Licenses to Academic Journals. PNAS, vol. 101, no. 3, (January 20): 897-902.

Galyani Moghaddam, G. 2006. Scholarly Electronic Journal Publishing: A Study Comparing Commercial and Non-profit/University Publishers. The paper has been accepted for publishing in the Serials Librarian, Vol. 51, No. 3/4, 2006.

Hoeffel C. Journal impact factors [letter]. Allergy (1998);53:1225

Kean, Gene. 2005. 18th Annual Study of Journal Prices for Scientific and Medical Society Journals: 2005 Pricing Trends for U.S. Society Journals and Ten Recommendations for Pricing 2006 Volumes. "JP, The Newsletter for Journal Publishers", Year 2005, No. 3. URL: http://www.allenpress.com/static/newsletters/pdf/JP-2005-03.pdf [Viewed January $12,2006]$.

Loughner, William. 1999. Top Ten Science Publishers Take 76 Percent of Science Budget. Newsletter on Serials Pricing Issues, No. 221, (May 20).

Rusch-Feja, Diann and Siebeky, Uta. 1999. Evaluation of Usage and Acceptance of Electronic Journals. D-Lib Magazine, (October). URL: http://www.dlib.org/dlib/october99/rusch-feja/10rusch-feja-summary.html [Viewed May 25, 2005].

Sales and Earnings Improve at Reed Elsevier. 2003. Publishers Weekly, vol. 250, no. 9 (March 3): 28.

Wilder, Stanley J. 1998. Comparing Value and Estimated Revenue of SciTech Journals. ARL Report, (October). Washington, DC: ARL. 